\title{
Uranium Removal from Wastewater Using Immobilized Multiple Heavy- Metal and Antibiotic Resistance E. coli Isolated from Aborshid Egypt
}

Mostafa G FadI, Mohamed Rezk, Maisa Mohamed Amin and Zenat Mohamed Kamel

Department of Microbiology, Cairo University, Egypt

*Corresponding author: Fadl MG, Department of Microbiology, Cairo University, Egypt, Tel: (+2)011-170 59788; E-mail: mostafa_gomaa338@yahoo.com

Received: October 16, 2017; Accepted: October 26, 2017; Published: November 07, 2017

Copyright: (c) 2017 Fadl MG, et al. This is an open-access article distributed under the terms of the Creative Commons Attribution License, which permits unrestricted use, distribution, and reproduction in any medium, provided the original author and source are credited.

\begin{abstract}
In this study 6 bacterial isolate, isolated Uranium Ore samples from Aborshid Egypt, were characterized for their response to 15 antibiotics and 10 heavy metals Beside Uranium. The results revealed a varying response of the Ore bacteria to the tested heavy metals. All isolates showed multiple metal resistance towards two to six heavy metals, with MIC ranging from 50 to $1000 \mathrm{ppm}$. The most potent of the strains in both groups were resistant to $\mathrm{Pb}, \mathrm{Ni}, \mathrm{Cu}$ and $\mathrm{Zn}$. highly metal-resistant bacteria could be used with potential application for treatment of wastewaters, using Immobilized Bacterial cells isolated from Egypt uranium Ore, Uranium removal from uranium refining wastewater, the most potent isolate was identified the Egyptian strains belong to $E$. coli, based on 16S rRNA gene sequencing the nucleotide sequences reported here were deposited to the NCBI Nucleotide Sequence Database under accession numbers (MF496270) by the name of Mostafa gomaa fadl.
\end{abstract}

Keywords: Aborshid; Immobilized bacteria; Resistance; Uranium; Antibiotics; Heavy metals; Phylogenetic tree; E. coli

\section{Introduction}

Enormous quantities of toxic metals are released into the environment annually as a result of human activities. In some cases, these releases are deliberate and well regulated, like industrial Waste, while in other cases they are accidental and include chemical spills or improper land disposal [1]. Heavy metals like $\mathrm{Pb}, \mathrm{Cr}$, uranium, selenium, zinc, Cd, gold, silver, copper, and nickel. Heavy metals released into the environment have, accumulation in food chains, and persistence in nature. These pollutants are derived from mining and fertilizer manufacture like phosphate fertilizer increased due to rapid industrialization and technological development, posing significant threats to Environment and Human health because of their toxicity [2].

The results for the determination of the effect of $\mathrm{pH}$ on $\mathrm{Cu}$ and $\mathrm{Cd}$ removal are shown at below $\mathrm{pH} 2$ conditions, $\mathrm{Cu}$ and $\mathrm{Cd}$ removal efficiencies were less than $61 \%$ and $38 \%$, respectively, while at higher than $\mathrm{pH} 3$ conditions, $\mathrm{Cu}$ and $\mathrm{Cd}$ removal efficiencies dramatically increased to over $95 \%$ [3]. These results suggest that $\mathrm{H}^{+}$can compete with $\mathrm{Cu}^{2+}$ or $\mathrm{Cd}^{2+}$ on the surface of Ca-alginate beads and hinder $\mathrm{Cu}^{2+}$ and $\mathrm{Cd}^{2+}$ biosorption at low $\mathrm{pH}$ however, $\mathrm{Cu}^{2+}$ or $\mathrm{Cd}^{2+}$ becomes relatively exchangeable with $\mathrm{Ca}^{2+}$ in Ca-alginate beads at higher than $\mathrm{pH} 3$ conditions [4].

From results of the batch experiments, it was found that the lowest $\mathrm{pH}$ limit for the use of Ca-alginate beads was $\mathrm{pH}$ 3. So our study on Phosphoric acid Which explain increase $\mathrm{PH}$ in phosphoric acid from 0.3 to 0.5 due exchanges These results suggest that $\mathrm{H}^{+}$can compete with $\mathrm{Cu}^{2+}$ or $\mathrm{Cd}^{2+}$ on the surface of Ca-alginate beads and hinder $\mathrm{U}$ biosorption at low $\mathrm{pH} \mathrm{U}$ becomes relatively exchanged with $\mathrm{Ca}^{2+}$ in $\mathrm{Ca}$-alginate beads at higher than $\mathrm{pH} 3$ or lower where even the initial $\mathrm{pH}$ of Phosphoric acid was $0.69(<3$ of $\mathrm{pH}$ ), the buffer effect of the Caalginate beads will increase the $\mathrm{pH}$. Controlling heavy metal discharges and removing toxic heavy metals from water bodies has become a challenge for the next generations where the fate of toxic metal species after they released to the environment becomes difficult. Additionally, they spread damage as they move from one ecological system to another. Trials used for heavy metal removal from industrial effluents can be classified as physical, chemical, and biological. Physicochemical methods such as precipitation, ion exchange, filtration, membrane and electrochemical technologies, reverse osmosis, electrodialysis, adsorption on activated carbon, etc., have disadvantage which is high capital and operating costs and may also be associated with the generation of secondary wastes which cause treatment problems. Therefore, recent attention has been drawn toward the development of alternative methodologies known as bioremediation processes.

Jackson et al. reported that the ability of microorganisms (Bacillus species, Pseudomonas species, Micrococcus species, Staphylococcus species) to tolerate pollution makes them useful in bioremediation due to adaptive nature of microorganism. The structures of cell walls play an important role in the adsorption process of metal ions. This may be due to the presence of positively charged cations of metal ions, which connect to negatively charged Binding sites in capsules or polymers on the cell wall by means electrostatic reactions [5]. Gram-positive bacteria exhibit more advantages in the biosorption process compared with Gram-negative bacteria due to the fact that Gram-positive bacteria have thick peptidoglycan cell walls that make them potentially more suitable for biosorption [6].

The walls of B. subtilis contain carboxylic groups of glutamic acid of peptidoglycan, which form the major site of metal adsorption. In $B$. licheniformis, teichoic acid and teichuronic acids are important binding sites [7]. Carbonyl, hydroxyl, imine, sulfonate, carboxyl, amine, thioether, imidazol, phosphodiester, phosphonate and amide groups are the important groups, which were used for the biosorption of metal ions in the bacterial cell wall [8]. 
Citation: Fadl MG, Rezk M, Amin MM, Kamel ZM (2017) Uranium Removal from Wastewater Using Immobilized Multiple Heavy-Metal and Antibiotic Resistance E. coli Isolated from Aborshid Egypt. Adv Recycling Waste Manag 2: 145. doi:10.4172/2475-7675.1000145

Page 2 of 10

\section{Immobilized biomass}

The use of an immobilized (palletized) biomass for industrial application, can improve biomass performance for heavy metal removal and makes recycle of biomass easier. due to the low density particle sizes, poor mechanical strength, and isolation of solid and liquid phase. The use of free bacterial cells for removal of heavy metals on a commercial scale may create problems. The immobilization of bacterial cells for heavy metal treatment from industrial effluents to overcome these shortcomings where immobilization of bacterial biomass by matrixes makes the biomass more stable, rigid, and heat resistant with porosity for practical applications, Therefore, it needs to consider that few efforts have been directed towards the remediation of heavy metals using immobilized bacterial biomass it was shown by the literature [9-11].

\section{Materials and Methods}

\section{Sampling}

U-resistant bacterial isolates were isolated from the rock ore aborshid using Nutrient Agar (NA) medium and were prepared using peptic digest of animal tissue $(5 \mathrm{~g} / \mathrm{L})$, beef extract $(3 \mathrm{~g} / \mathrm{L}), \mathrm{NaCl}(5 \mathrm{~g} / \mathrm{L})$ and agar $15 \mathrm{~g} / \mathrm{L}$. Rock analysis of Lamprophyte aborshide shown in Table 1 .

\begin{tabular}{|l|l|}
\hline Elements & Percentage \\
\hline $\mathrm{SiO}_{2}$ & $43.87 \%$ \\
\hline $\mathrm{Al}_{2} \mathrm{O}_{2}$ & $19.32 \%$ \\
\hline $\mathrm{TiO}_{2}$ & $3.6 \%$ \\
\hline $\mathrm{FeO}_{3}$ & $15.97 \%$ \\
\hline $\mathrm{Ca}$ & $1.54 \%$ \\
\hline $\mathrm{Mg}$ & $0.81 \%$ \\
\hline $\mathrm{Na}$ & $1 \%$ \\
\hline $\mathrm{K}$ & $1.6 \%$ \\
\hline $\mathrm{P}_{2} \mathrm{O}_{5}$ & $0.8 \%$ \\
\hline Loss of ignition & $7.66 \%$ \\
\hline Uranium & $400 \mathrm{pm}$ \\
\hline
\end{tabular}

Table 1: Rock analysis of aborshid ore.

\section{Isolation and identification of heavy metal-resistant bacteria from rock ore}

The isolated metal-resistant bacteria were amended with different conc. of U-metal. Pour plate was performed in NA medium and was incubated at $37^{\circ} \mathrm{C}$ for $24 \mathrm{~h}$. The most potent isolate was identified the Egyptian strains belong to $E$. coli, based on $16 \mathrm{~S}$ rRNA gene sequencing the nucleotide sequences reported here were deposited to the NCBI Nucleotide Sequence Database under accession numbers (MF496270) by the name of Mostafa gomaa fadl.

\section{Preparation of $E$. coli capsule}

We reported alginate-chitosan as a E. coli, Capsule E. coli, Capsule/ alginate-chitosan microcapsule was composed of E. coli sodium alginate, chitosan and calcium chloride. Therefore, in sterile conditions, Bacillus species was mixed with sodium alginate solution, and then the mixed solution was dropped into calcium chloride solution to immobilize using microcapsule preparation instrument. $E$. coli Capsule loaded calcium alginate gel beads were obtained after immobilizing, and Bacillus species loaded calcium alginate gel beads were mixed with chitosan solution to obtain the E. coli Capsule / alginate-chitosan microcapsule. The microcapsule system had good mechanical strength, flexibility and biocompatibility between $E$. coli Capsule and microcapsule. In addition, internal three-dimensional network structure of the microcapsule provided a sufficient space for E. coli Capsule. Growth and good encapsulating stability $[13,14]$.

\section{Study area and microorganisms}

The 24 bacterial strains used in the present study were isolated previously in the Nuclear Materials Authority from samples collected on two Aborshid, Egypt. 6 Isolates, designated S6, were The Egyptian strains belong to $E$. coli, based on 16S rRNA gene sequencing [15]. The pure cultures were stored at $+4^{\circ} \mathrm{C}$ and recultured on nutrient agar slants every 2 months to maintain their purity and viability. Suspensions of pure cultures mixed with $30 \%(\mathrm{v} / \mathrm{v})$ glycerol were stored at $-80^{\circ} \mathrm{C}$.

\section{Antibiotic susceptibility and resistance tests}

The Antarctic bacteria were checked for antibiotic resistance with the following antibiotics: ciprofloxacin $(\mathrm{Cp}, 5 \mu \mathrm{g})$, gentamicin $(\mathrm{G}, 10$ $\mu \mathrm{g})$, amikacin $(\mathrm{Am}, 30 \mu \mathrm{g})$, tobramycin $(\mathrm{Tb}, 10 \mu \mathrm{g})$, novobiocin $(\mathrm{Nb}, 5$ $\mu \mathrm{g})$, lincomycin $(\mathrm{L}, 15 \mu \mathrm{g})$, tetracycline $(\mathrm{T}, 30 \mu \mathrm{g})$, ampicillin (A, 10 $\mu \mathrm{g})$, chloramphenicol (C, $30 \mu \mathrm{g})$, vancomycin $(\mathrm{V}, 30 \mathrm{mg})$, erythromycin $(\mathrm{E}, 15 \mu \mathrm{g})$, kanamycin $(\mathrm{K}, 30 \mu \mathrm{g})$ and cefazolin $(\mathrm{Cfz}, 30 \mu \mathrm{g})$. Antibiotic susceptibility of the strains was assayed following the Kirby-Bauer disc diffusion method [16] on Peptone Yeast Extract Agar (PYA) medium. Aliquots of each bacterial suspension grown exponentially in nutrient broth were spread on the surface of PYA plates.

Antibiotic discs (Bul Bio; NCIPD, Sofia, Bulgaria) impregnated with known amounts of antibiotics were placed aseptically on the surface of the inoculated plates and incubated at $18 \pm 2^{\circ} \mathrm{C}$ for $24 \mathrm{~h}$. After incubation, the organisms were classified as sensitive or resistant to each antibiotic according to the diameter of inhibition zones.

\section{Heavy metal resistance tests}

The Aborshid bacteria were screened for their heavy metal resistance patterns using the agar well diffusion method (Hassen et al.). Ten heavy metals-chromium $(\mathrm{Cr})$, copper $(\mathrm{Cu})$, nickel $(\mathrm{Ni})$, cobalt $(\mathrm{Co})$, cadmium $(\mathrm{Cd})$, zinc $(\mathrm{Zn})$ and lead $(\mathrm{Pb})$-were used as Standard: respectively. In a preliminary test, $0.05 \%(\mathrm{w} / \mathrm{v})$ metal salt solutions were prepared in distilled water and sterilized in a boiling water bath for $20 \mathrm{~min}$. Sterile PYA plates were prepared and wells $(7 \mathrm{~mm}$ in diameter) were punched by a sterile borer. After inoculation of the plates with overnight grown indicator cultures, $100 \mu \mathrm{l}$ of each metal salt solution was added to the wells. After incubation of the plates at $18-20^{\circ} \mathrm{C}$ for $48 \mathrm{~h}$, the inhibition (sterile) zones were measured as an indicator of resistance/sensitivity. Zones were recorded as the distance from the edge of the zone to the edge of the well. Isolates showing a clear zone of $1 \mathrm{~mm}$ or less were considered as resistant strains [17]. The 
Page 3 of 10

minimum inhibitory concentration (MIC) of metal ions for the Antarctic bacteria was determined by gradually increasing or decreasing the heavy metal concentrations in the following cationic concentration ranges (mM): Cu: 0.2-24; Cd: 0.14-14.2; Ni: 3.8-46; Cr: 1.4-17; $\mathrm{Zn:}$ 0.2-20.8; Co: $0.2-21 ; \mathrm{Pb}: 1.3-26$. The MIC value was defined as the lowest concentration of metal ion at which a visible inhibition (clear) zone of 1-2 $\mathrm{mm}$ around the well was observed after incubation of the plates at $18-20^{\circ} \mathrm{C}$ for $48 \mathrm{~h}$ [18]. Strains that were not inhibited by a concentration of heavy metals less than $1.0 \mathrm{mM}$ were regarded as resistant [19].

\section{Determination of uranium}

The uranium content of the sample and prepared standard and treated solution were determined according to the method described by Davies and Gray [20].

\section{Reagent:}

1. Orthophosphoric acid $\left(\mathrm{H}_{3} \mathrm{PO}_{4}, 85 \%\right)$,

2. Concentration $(\mathrm{HCl}, 32 \%)$,

3. $10 \%$ ammonium ferrus Sulphate (10 gm A.F. $\mathrm{S}+10 \mathrm{ml} \mathrm{H}_{2} \mathrm{SO}_{4}$ concentration then up to volume $100 \mathrm{ml}$ with Dist),

4. Titanium trichloride $\left(\mathrm{TiCl}_{3}\right)$,

5. Sodium nitrite $\left(\mathrm{NaNO}_{2}\right)$,

6. $20 \%$ Urea Solution,

7. Indicator Sodium salt ( $0.2 \mathrm{gm}$ diphenyl amino-4-sulfonic acid sodium salt +0.2 sodium carbonate, then add drops of dist $\mathrm{H}_{2} \mathrm{O}$ with stirring and up to volume $100 \mathrm{ml}$ ),

8. Ammonium meta vanidate $\left(\mathrm{NH}_{4} \mathrm{VO}_{3}\right)$.

\section{Methodology}

- $5 \mathrm{ml}$ of uranium sample were taken in a dry and clean $100 \mathrm{ml}$ Erlenmeyer flask, then the following chemicals were added in the same order.

- $10 \mathrm{ml}$ double distilled water.

- $10 \mathrm{ml}\left(\mathrm{H}_{3} \mathrm{PO}_{4}\right)$.

- $1 \mathrm{ml}$ conc. $(\mathrm{Hcl})$.

- 5 drops of $10 \%$ ammonium ferrus sulphate.

- 3 drops of $\mathrm{TiCl}_{3}$ were added till the solution changed to purplish color.

- The reaction was leaved for $5 \mathrm{~min}$.

- 3 drops of $15 \% \mathrm{NaNO}_{2}$ were added till the brown yellowish color appears then disappear. Immediately $5 \mathrm{ml}$ of (urea 20\%) were added and followed by rapid shaking till the air bubbles were stopped.

- The reaction was leaved again for 2 minutes befor adind the indicator.

- 2 drops of indicator sodium salt were added.

- Titration against 0.1 Ammonium metavanadates was performed till the end point of pale violet color appeared.

- The uranium concentration will be calculated according to the following equation:

\section{$\mathrm{U}(\mathrm{mg} / \mathrm{l})=\mathrm{T} \times \mathrm{V} 1 \times 10^{3} / \mathrm{v}$}

Where (T) is the titration intensity of $\mathrm{NH}_{4} \mathrm{VO}_{3}$ Solution, (V1) is the consumed volume of $\mathrm{NH}_{4} \mathrm{VO}_{3}$ Solution and (v) solution is the volume of the measured sample [20] and developed by Nuclear Materials Authority.

\section{Results and Discussion}

Table 2 represents that 6-10 Isolates tested for incubation with different conc. of Uranium and investigate strong of growth against $U$ conc. It was found that the most potent isolate S6, S5 which it's Growth continue with stability up to $1000 \mathrm{ppm}$ Uranium conc.

\begin{tabular}{|l|l|l|l|l|l|}
\hline $\begin{array}{l}\text { Uranium conc. } \\
\text { Isolate number }\end{array}$ & $100 \mathrm{ppm}$ & $200 \mathrm{ppm}$ & $300 \mathrm{ppm}$ & $600 \mathrm{ppm}$ & $1000 \mathrm{ppm}$ \\
\hline S6 & ++ & + & + & + & + \\
\hline S4 & + & + & + & + & + \\
\hline S5 & + & + & + & + & + \\
\hline S7 & + & + & + & \pm & \pm \\
\hline S8 & \pm & - & - & - & - \\
\hline
\end{tabular}

Table 2: Test for Screening of uranium resistant isolates.

\section{Antibiotic resistance and sensitivity of the (E. coli mos) as defined bacteria Aborshid Egypt}

Bacterial resistance to antibiotics is an extensively investigated phenomenon of considerable medical importance [21]. Resistant bacteria are common in the natural environment, especially in aquatic habitats [22], and even in habitats that seem unlikely to have been exposed to anthropogenic antibiotics [23,24]. It has long been recognized that specific antibiotic resistance mechanisms can be acquired through mutation of the bacterial genome or by gaining additional genes; different physiological states are also important for the survival of bacteria in the presence of antibiotics. Antibiotic resistance genes are often located on plasmids that are able to transfer horizontally among diverse bacterial populations, thus contributing to the widespread dissemination of antibiotic resistance in the environment [25,26]. Antibiotic resistance has also been reported among bacteria in cold environments.

The resistance patterns to 13 antibiotics in the (E. coli mos) Aborshid bacteria were determined and the results are shown in Table 1. Six strains showed multiple antibiotic resistance, and only Bacillus species A2-4 was sensitive to all target antibiotics. Bacteria of both tested groups showed a high degree of multiple antibiotic resistance, most frequently towards lincomycin (79\%), cefazolin (75\%), ampicillin (71\%), novobiocin and erythromycin (62\%), chloramphenicol and vancomycin (58\%), and tetracycline (42\%). A high frequency of bacteria resistant to antibiotics can be viewed as an indicator of environmental pollution [27]. Isolation of antibiotic-resistant bacteria from areas with limited human activity can be a good indicator of human impact on these natural areas, such as Aborshid Egypt [28]. The relatively high percentage of multidrug resistant bacteria determined in this study (79\%) may suggest medium anthropogenic impact in these Antarctic regions.

\section{Heavy metal resistance of the Antarctic bacteria}

Aborshid bacteria (E. coli mos) were investigated for resistance to ten heavy metals, and MICs for each metal ion were determined. A varying response of bacterial strains of $E$. coli mos to the tested heavy metals was observed (Table 3). Although there is no currently acceptable concentration of metal ions, which could be used for distinguishing metal resistant and metal-sensitive bacteria, strains able 
Citation: Fadl MG, Rezk M, Amin MM, Kamel ZM (2017) Uranium Removal from Wastewater Using Immobilized Multiple Heavy-Metal and Antibiotic Resistance E. coli Isolated from Aborshid Egypt. Adv Recycling Waste Manag 2: 145. doi:10.4172/2475-7675.1000145

Page 4 of 10

to grow at concentrations of metal ions at and above $10 \mathrm{ppm}$ were considered resistant, as suggested by Malik and Jaiswal [19]. The highest MIC values of each heavy metal determined for S6 and S5 strains were compared (Figure 1). For S6 strains (Figure 2), the observed similar order of resistance to metals of both groups of strains (according to the highest MICs) probably relates to the metal concentrations in the sampling areas. Lo Giudice et al. found tolerance to the heavy metals of bacterial isolates from Aborshid Ore (in the order $\mathrm{Ph}>\mathrm{Cu}>\mathrm{Ni}>\mathrm{Mo}>\mathrm{Ti}>\mathrm{Cr}>\mathrm{Cd}>\mathrm{Mo}>\mathrm{Zr}$, which appeared to be strictly related to the metal concentrations in the study area (Figure 3) [29]. The present results revealed a high multi metal resistance of both groups of strains: all S6 strains exhibited resistance to four to ten metal ions, and $92 \%$ of A2 strains were resistant to three to six metal ions (Figure 4). Although Industrial waste are considered the natural collectors of pollutants (Table 4) [30], the frequency of metal resistance of S5 ore isolates was found to be comparable to that of S6 soil isolates. All $\mathrm{S} 5$ strains were found to be resistant to $\mathrm{Pb}, \mathrm{Cu}$ and $\mathrm{Ni}$ ions, and. The majority of the strains in each group (75\%) were found to be sensitive.

\section{Identification of bacterial isolates}

Isolation and biochemical identification of $E$. coli from industrial wastewater effluents. 16 samples were collected from Rock Sample in aborshid. The results revealed that E. coli was found in higher concentration Uranium. Wastewater is an important reservoir for $E$. coli and presented significant acute toxicity if released into the receiving water body without being adequately treated. Results revealed the presence of both gram negative and positive bacteria. There was non significant variation among all the samples of wastewater. The highest concentration of $E$. coli was observed in Rock Sample of Uranium industry Site. Biochemical and Confirmed by $16 \mathrm{~S}$ ribosomal RNA Sequencing and phylogenetic Tree confirmed that S6 isolate is that E. coli.

E. coli was cultured on LB medium and MacConkey medium for morphological characterization. After $24 \mathrm{hrs,} \mathrm{two} \mathrm{types} \mathrm{of} \mathrm{colonies}$ were isolated under microscopic examination. All the isolated colonies were pink on MacConkey medium, while creamy yellow on LB medium. E. coli was observed in highest concentration from Rock samples of industry (aborshid A) whereas in Rock samples of industry (aborshid B) six samples indicated the presence of $E$. coli which was confirmed by $16 \mathrm{~S}$ ribosomal RNA Sequencing and phylogenetic Tree. Four samples were of gram positive bacteria which may be $B$. subtilus or B. thuringiensis. In Rock Sample (aborshid C) eight samples were of gram negative while two samples were of gram positive bacteria. It was observed that Rock (aborshid A) revealed most potent of Uranium resistant isolates of gram negative bacteria.

Isolation and biochemical identification of $E$. coli from industrial wastewater effluents. 16 samples were collected from Rock Sample in aborshid. The results revealed that E. coli was found in higher concentration Uranium. Wastewater is an important reservoir for $E$. coli and presented significant acute toxicity if released into the receiving water body without being adequately treated. Results revealed the presence of both gram negative and positive bacteria. There was non-significant variation among all the samples of wastewater. The highest concentration of E. coli was observed in Rock Sample of Uranium Industry Site. Biochemical and Confirmed by $16 \mathrm{~S}$ ribosomal RNA Sequencing and phylogenetic Tree confirmed that S 6 isolate is that E. coli.

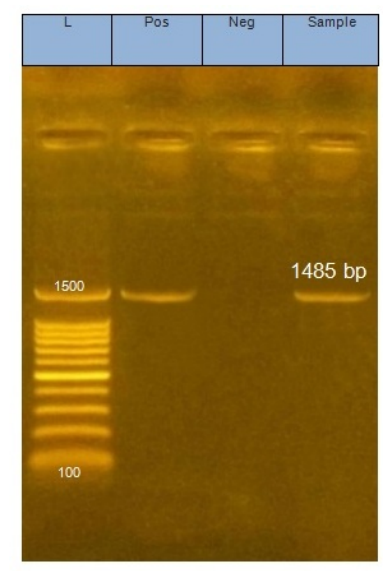

Figure 1: (S6) Sample gave good band and purified 16S rRNA photo details.

E. coli was cultured on LB medium and MacConkey medium for morphological characterization. After $24 \mathrm{hrs}$, two types of colonies were isolated under microscopic examination. All the isolated colonies were pink on MacConkey medium, while creamy yellow on LB medium. E. coli was observed in highest concentration from Rock samples of industry (aborshid A) whereas in Rock samples of industry (aborshid B) six samples indicated the presence of $E$. coli which was confirmed by $16 \mathrm{~S}$ ribosomal RNA Sequencing and phylogenetic Tree. Four samples were of gram positive bacteria which may be Bacillus subtilus or Bacillus thuringiensis. In Rock Sample (aborshid C) eight samples were of gram negative while two samples were of gram positive bacteria. It was observed that Rock (aborshid A) revealed most potent of Uranium resistant isolates of gram negative bacteria.

\section{Nucleotide sequence accession numbers}

The nucleotide sequences reported here were deposited to the NCBI Nucleotide Sequence Database under accession numbers (MF496270) by the name of Mostafa gomaa fadl.

\section{Correlation between multiple antibiotic resistance and uranium and heavy-metal tolerance among some $E$. coli isolated from Aborshid Egypt}

The aim of this preliminary screening of antibiotic sensitivity was to find possible correlation between antibiotic resistance and heavy-metal resistance patterns of 12 E. coli strains isolated from Uranium ore. 
Citation: Fadl MG, Rezk M, Amin MM, Kamel ZM (2017) Uranium Removal from Wastewater Using Immobilized Multiple Heavy-Metal and Antibiotic Resistance E. coli Isolated from Aborshid Egypt. Adv Recycling Waste Manag 2: 145. doi:10.4172/2475-7675.1000145
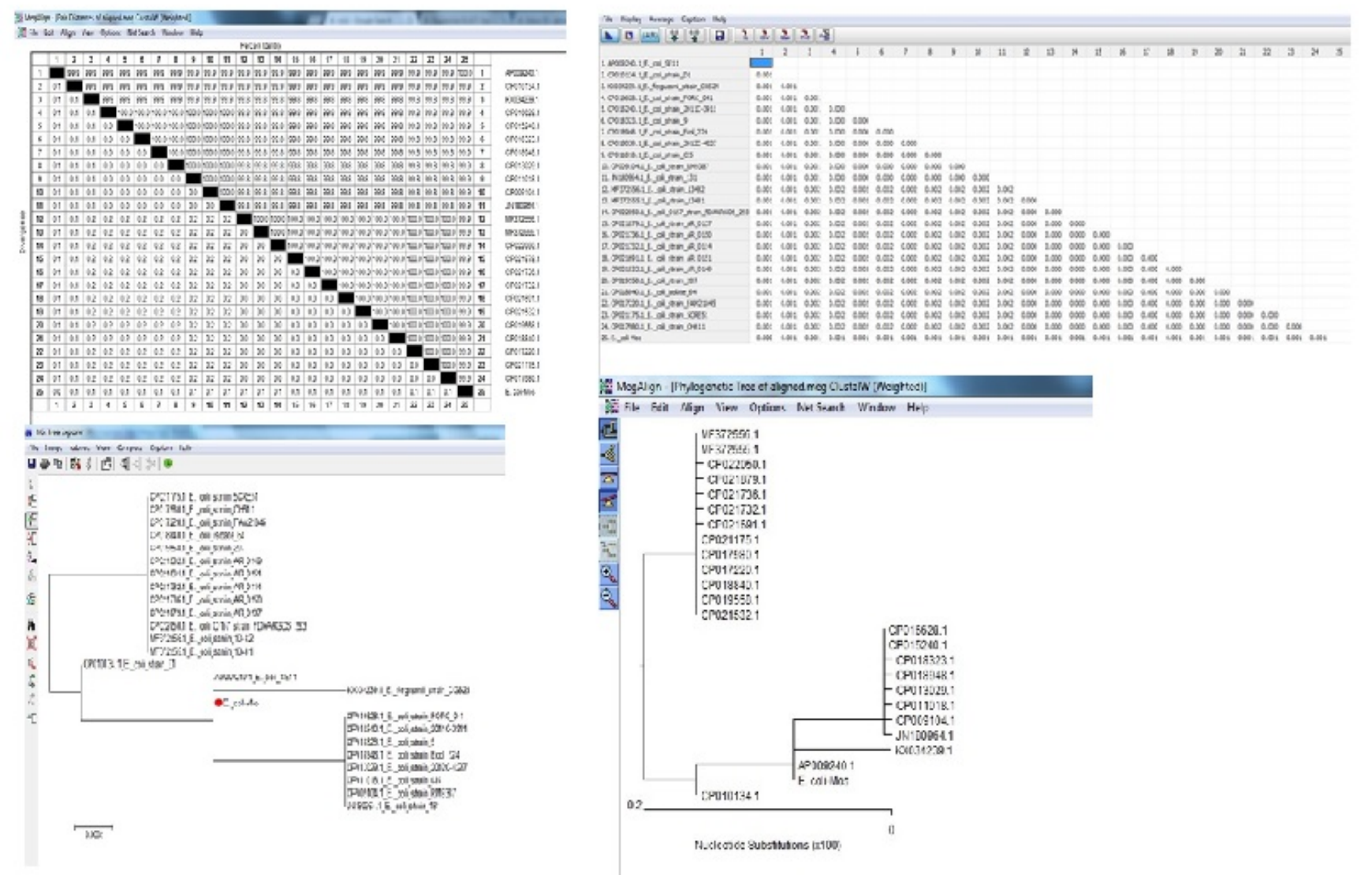

Figure 2: Merged Figure showing 16s rRNA and Phylogenetic Tree.

\begin{tabular}{|c|c|c|c|c|c|}
\hline $\begin{array}{l}\text { Uranium conc. } \\
\text { Isolate number }\end{array}$ & 100 ppm & 200 ppm & 300 ppm & 600 ppm & $1000 \mathrm{ppm}$ \\
\hline S6 & ++ & + & + & + & + \\
\hline S4 & + & + & + & + & + \\
\hline S5 & + & + & + & + & + \\
\hline S7 & + & + & + & \pm & \pm \\
\hline S8 & \pm & - & - & - & - \\
\hline
\end{tabular}

Table 3: Screening of Bacterial Isolates against different Uranium concentration.

\begin{tabular}{|c|c|c|c|c|c|c|c|c|c|}
\hline E. coli (S6) & $\mathrm{Ph}$ & $\mathrm{Cr}$ & $\mathrm{Cu}$ & Co & $\mathrm{Ni}$ & Cd & Mo & $\mathrm{Zr}$ & $\mathrm{Ti}$ \\
\hline 100 & $\mathrm{R}$ & $\mathrm{R}$ & $\mathrm{R}$ & $\mathrm{R}$ & $R$ & $\mathrm{R}$ & $\mathrm{R}$ & $\mathrm{R}$ & $\mathrm{R}$ \\
\hline 200 & $\mathrm{R}$ & $\mathrm{R}$ & $\mathrm{R}$ & $R$ & $R$ & $\mathrm{R}$ & $\mathrm{R}$ & $R$ & $\mathrm{R}$ \\
\hline 400 & $R$ & $\mathrm{R}$ & $\mathrm{R}$ & $R$ & $R$ & $\mathrm{R}$ & $\mathrm{R}$ & $\mathrm{R}$ & $\mathrm{R}$ \\
\hline 600 & $R$ & $\mathrm{R}$ & $\mathrm{R}$ & $R$ & $R$ & $\mathrm{R}$ & $\mathrm{R}$ & $\mathrm{R}$ & $R$ \\
\hline 1000 & $R$ & $5 \mathrm{ml}$ & $2 \mathrm{ml}$ & $5 \mathrm{ml}$ & $2 \mathrm{ml}$ & $5 \mathrm{ml}$ & $1 \mathrm{ml}$ & $4 \mathrm{ml}$ & $2 \mathrm{ml}$ \\
\hline
\end{tabular}


Citation: Fadl MG, Rezk M, Amin MM, Kamel ZM (2017) Uranium Removal from Wastewater Using Immobilized Multiple Heavy-Metal and Antibiotic Resistance E. coli Isolated from Aborshid Egypt. Adv Recycling Waste Manag 2: 145. doi:10.4172/2475-7675.1000145

Page 6 of 10

\begin{tabular}{|l|l|l|l|l|l|l|l|l|l|}
\hline (S5) & $\mathrm{Ph}$ & $\mathrm{Cr}$ & $\mathrm{Cu}$ & $\mathrm{Co}$ & $\mathrm{Ni}$ & $\mathrm{Cd}$ & $\mathrm{Mo}$ & $\mathrm{Zr}$ & $\mathrm{Ti}$ \\
\hline 100 & $\mathrm{R}$ & $\mathrm{R}$ & $\mathrm{R}$ & $\mathrm{S}$ & $\mathrm{R}$ & $\mathrm{S}$ & $\mathrm{S}$ & $\mathrm{S}$ & $\mathrm{S}$ \\
\hline $\mathrm{S}$ (Bacillus) & $\mathrm{Ph}$ & $\mathrm{Cr}$ & $\mathrm{Cu}$ & $\mathrm{Co}$ & $\mathrm{Ni}$ & $\mathrm{Cd}$ & $\mathrm{Mo}$ & $\mathrm{Zr}$ & $\mathrm{Ti}$ \\
\hline 100 & $\mathrm{~S}$ & $\mathrm{~S}$ & $\mathrm{~S}$ & $\mathrm{~S}$ & $\mathrm{~S}$ & $\mathrm{~S}$ & $\mathrm{~S}$ & $\mathrm{~S}$ & $\mathrm{~S}$ \\
\hline
\end{tabular}

Table 4: Screening of Bacterial Isolates against different Heavy metal concentration.

In soil and water, multiple antibiotic resistances is clearly associated with resistance/tolerance to heavy-metals $\left(\mathrm{Hg}^{2+}, \mathrm{Cu}^{2+}, \mathrm{Pb}^{2+}, \mathrm{Zn}^{2+}\right.$, $\mathrm{Ca}^{2+}$ ). For different genera the genes for heavy-metals resistance are often plasmid encoded. Since these genes are clustered on the same plasmids, heavy-metals and drugs are environmental factors which exert a selective pressure for the populations of these plasmid- harboring bacteria. Antimicrobial susceptibility testing was performed for ampicillin, tetracycline, gentamycin, kanamycin, chloramphenicol, ceftazidime and cefotaxime by standard disk diffusion. These antibiotics were chosen because of their wide-spread use and importance in the treatment of Gram-negative bacterial infections (Table 5).

\begin{tabular}{|c|c|c|c|c|c|}
\hline \multicolumn{3}{|l|}{ Isolate } & \multicolumn{3}{|c|}{ Inhibition zone diameter(mm) } \\
\hline \multirow{2}{*}{ E. coli S6 } & Antibiotic & Amount on disc & Resistant & Intermediate & Sensitive \\
\hline & Ampicillin ${ }^{b}$ & $10 \mu g$ & 11 or less & $12-13$ & 14 or more \\
\hline $\mathrm{R}$ & Ampicillinc & $10 \mu \mathrm{g}$ & 28 or less & - & 29 or more \\
\hline S & Cephoxitin & $30 \mu \mathrm{g}$ & 14 or less & $15-17$ & 18 or more \\
\hline S & Cephalotin & $30 \mu \mathrm{g}$ & 14 or less & $15-17$ & 18 or more \\
\hline S & Chloramphenicol & $30 \mu \mathrm{g}$ & 12 or less & $13-17$ & 18 or more \\
\hline S & Clindamycin & $2 \mu \mathrm{g}$ & 14 or less & $15-16$ & 17or more \\
\hline I & Erytromycin & $15 \mu \mathrm{g}$ & 13 or less & $14-17$ & 18 or more \\
\hline S & Gentamycin & $10 \mu \mathrm{g}$ & 12 or less & $13-14$ & 15 or more \\
\hline 1 & Kanamycin & $30 \mu \mathrm{g}$ & 13 or less & $14-17$ & 18 or more \\
\hline 1 & Methicillinc & $5 \mu \mathrm{g}$ & 9 or less & Oct-13 & 14 or more \\
\hline I & Neomycin & $30 \mu \mathrm{g}$ & 12 or less & $13-16$ & 17 or more \\
\hline S & Nitrofurantoin & $300 \mu \mathrm{g}$ & 14 or less & $15-16$ & 17 or more \\
\hline $\mathrm{R}$ & Penicillin Gd & 10 units & 28 or less & - & 29 or more \\
\hline $\mathrm{R}$ & Penicillin Ge & 10 units & 11 or less & Dec-21 & 22 or more \\
\hline I & Polymyxin B & 300 units & 8 or less & 09-Nov & 12 or more \\
\hline$R$ & Streptomycin & $10 \mu \mathrm{g}$ & 11 or less & Dec-14 & 15 or more \\
\hline $\mathrm{R}$ & Tetracycline & $30 \mu \mathrm{g}$ & 14 or less & $15-18$ & 19 or more \\
\hline $\mathrm{s}$ & $\begin{array}{l}\text { Trimethoprim-Sulfamethoxazole } \\
\text { (SXT) }\end{array}$ & $1.25 / 23.75 \mu \mathrm{g}$ & 10 or less & Nov-15 & 16 or more \\
\hline $\mathrm{R}$ & Tobramycin & $10 \mu \mathrm{g}$ & 12 or less & $13-14$ & 15 or more \\
\hline $\mathrm{R}$ & Novobiocin & $30 \mu \mathrm{g}$ & 17 or less & $18-21$ & 22 or more \\
\hline
\end{tabular}

Table 5: Screening of Bacterial Isolates against different antibiotic disc.

\section{Kirby-Bauer}

MICs values of antibiotics and heavy-metals were determined by dilution method in Mueller-Hinton broth using an inoculum of about
1-2 $\times 10^{8} \mathrm{CFU} / \mathrm{ml}$. The concentration range for antimicrobials and heavy-metals Standard (Cu, Cd, Co, Cr, P, Pb, Ni, Mo, Zr, U, ) was 100-1000 Samples (S6) resistant to ampicillin and colistin sulphate and doxycycline and penicillin and streptomycin and tetracycline. The 
Citation: Fadl MG, Rezk M, Amin MM, Kamel ZM (2017) Uranium Removal from Wastewater Using Immobilized Multiple Heavy-Metal and Antibiotic Resistance E. coli Isolated from Aborshid Egypt. Adv Recycling Waste Manag 2: 145. doi:10.4172/2475-7675.1000145

Page 7 of 10

phenotypic data shows the direct association between multiple antibiotic and heavy-metal resistance for $E$. coli strains in polluted water (Table 6).

\section{Uranium removal from uranium wastewater using immobilized $E$. coli cells isolated from Egypt uranium ore aborshid}

As mentioned, some microbial species have a high $U$ accumulating ability, which suggests the possibility that they may be used for the removal of $\mathrm{U}$ from $\mathrm{U}$ wastewater, and other waste sources (Table 7).

\begin{tabular}{|l|l|l|}
\hline \multirow{2}{*}{ Strain (Isolate no) } & \multicolumn{2}{|c|}{ Removed U (\%) } \\
\cline { 2 - 3 } & $\begin{array}{l}|c| \\
\mathrm{pH} \text { adjusted only started } \\
\text { at } \mathrm{pH} 6.0\end{array}$ & $\begin{array}{l}\mathrm{pH} \text { adjusted continuously at } \\
\mathrm{pH} 6.0\end{array}$ \\
\hline E. coli (S6) & $98 \%$ & $100 \%$ \\
\hline
\end{tabular}

Table 6: Uranium removal from uranium wastewater using by adjusting $\mathrm{PH}$.

\begin{tabular}{|l|l|}
\hline Strains & Adsorbed uranium $\mathbf{U}(\%)$ \\
\hline E. coli $(\mathrm{S} 6)$ & $100 \%$ \\
\hline
\end{tabular}

Table 7: Uranium removal from uranium wastewater using immobilized microorganisms isolated from uranium ore.

We attempted to remove $\mathrm{U}$ from $\mathrm{U}$ Lab. wastewater sampled at Nuclear Materials Authority using bacteria exhibiting a significant ability to accumulate U. Viable cells of E. coli were suspended in 100 $\mathrm{mL}$ of a solution immobilized bacteria $(\mathrm{pH}$ 6.0) of wastewater containing $\mathrm{U}$ for $1 \mathrm{~h}$ at $25^{\circ} \mathrm{C}$. E. coli isolated from Egypt $\mathrm{U}$ ore removed $90 \%$ and $78 \% \mathrm{U}$, respectively (Table $7 \mathrm{a}-7 \mathrm{~b}$ ), when solution $\mathrm{pH}$ was adjusted initially to 6.0. Solution $\mathrm{pH}$ gradually decreased, with $E$. coli cells being more adversely affected by $\mathrm{pH}$. However, strains quantitatively removed $\mathrm{U}$ when the $\mathrm{pH}$ was maintained at 6.0. These species can thus remove $U$ from $U$ refining wastewater with a high efficiency.

\section{Analyzed the FTIR spectra of U loaded and unloaded}

FTIR spectra is used as to confirm availability of binding sites as shown in Table $5 \mathrm{a}-5 \mathrm{~b}$ for Uranium we found Amino acid $(\mathrm{O}-\mathrm{H})$ stretching protein $\mathrm{v}(\mathrm{N}-\mathrm{H})$ stretching, Phosphate C-O Stretching band,
P-H stretching, Protein amide-I band mainly $(\mathrm{C}=\mathrm{O})$ Streching, Protien $\left(\mathrm{CH}_{2}\right)$ and $\left(\mathrm{CH}_{3}\right)$ bending of methyle Lipid $\left(\mathrm{CH}_{2}\right)$ bending of methyl, Carbohydrate $(\mathrm{C}-\mathrm{O})$ of polysaccharides, Nucleic acid (other phosphate containing compound) $>\mathrm{P}=\mathrm{O}$ stretching of phosphodiester, acid chlorides $\mathrm{C}-\mathrm{Cl}$ stretch in $\mathrm{S} 6 \mathrm{E}$. coli, and comparing with dead isolate we found the same beside acid chlorides at position $550 \mathrm{~cm}^{-1}, \mathrm{C}-\mathrm{Cl}$ stretch Cayllahua et al. study who used FTIR spectra to confirm the presence of amide, carboxyl, and phosphate groups in Rhodococcus species Biomass.

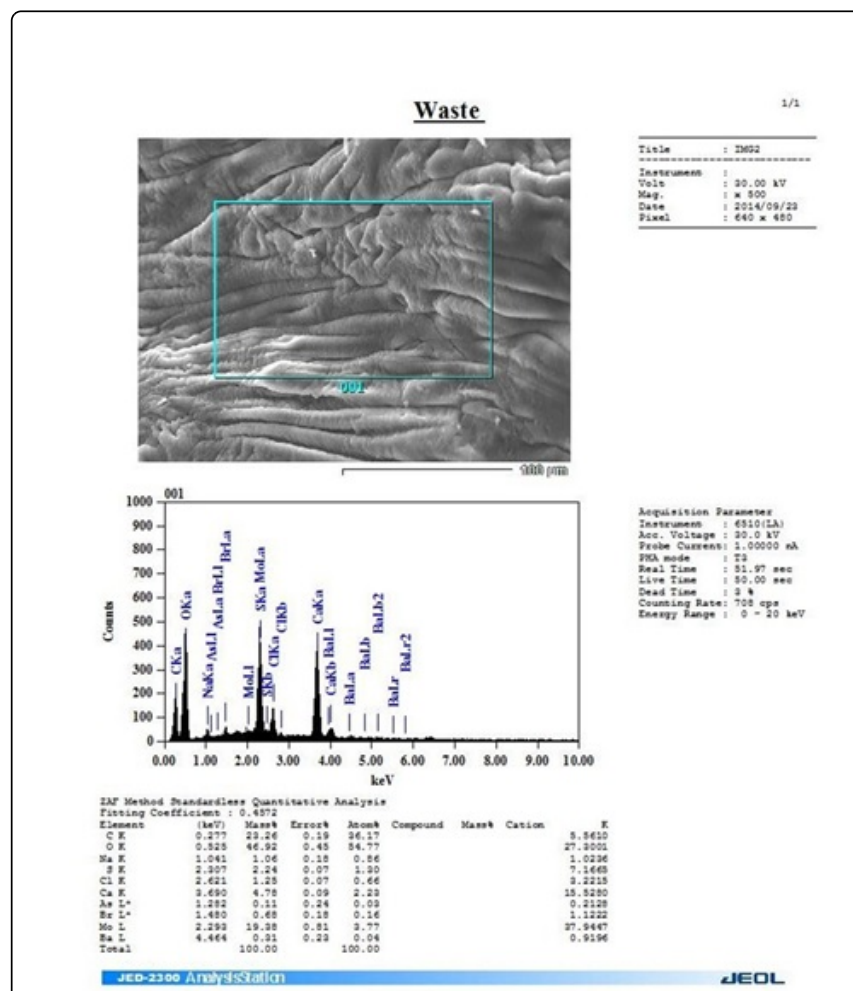

Figure 3: EDX to confirm biosorption of $U$ by cell free extract loaded Ca-Alginate beads.

Several band transformations allowed the authors to predict the possible involvement of amino, carbonyl, carboxyl, and phosphate groups in the biosorption of $\mathrm{Cd}^{2+}$.

\begin{tabular}{|c|c|c|c|}
\hline Main peak $\left(\mathrm{cm}^{-1}\right)$ & $\begin{array}{l}\text { Intensity of loaded band live } \\
\text { bacteria }\end{array}$ & Typical band & Wave number range \\
\hline $1-3439.42$ & 77.9 & $\begin{array}{l}\text { Amino acid }(\mathrm{O}-\mathrm{H}) \text { stretching protein } \mathrm{v}(\mathrm{N}-\mathrm{H}) \\
\text { stretching }\end{array}$ & $3029-3639$ \\
\hline $2-2355.62$ & 93 & Phosphate C-O Stretching band, P-H stretching & $2344-2365$ \\
\hline $3-1638.23$ & 90 & Protein amide I band mainly $(C=O)$ Stretching & 1583-1709 \\
\hline $4-1428.99$ & 95 & $\begin{array}{l}\text { Protein }\left(\mathrm{CH}_{2}\right) \text { and }\left(\mathrm{CH}_{3}\right) \text { bending of methyl Lipid } \\
\left(\mathrm{CH}_{2}\right) \text { bending of methyl }\end{array}$ & $1425-1477$ \\
\hline $5-1101.15$ & 100 & $\begin{array}{l}\text { Carbohydrate }(\mathrm{C}-\mathrm{O}) \text { of polysaccharides, Nucleic } \\
\text { acid (other phosphate containing compound) } \\
>p=0 \text { stretching of phosphodiester }\end{array}$ & $1072-1356$ \\
\hline
\end{tabular}


Citation: Fadl MG, Rezk M, Amin MM, Kamel ZM (2017) Uranium Removal from Wastewater Using Immobilized Multiple Heavy-Metal and Antibiotic Resistance E. coli Isolated from Aborshid Egypt. Adv Recycling Waste Manag 2: 145. doi:10.4172/2475-7675.1000145

Page 8 of 10

\begin{tabular}{|l|l|l|l|}
\hline $6-556.363$ & 97 & acid chlorides C-Cl stretch & $730-550$ \\
\hline
\end{tabular}

Table 7a: Data of FT-IR OF unloaded E. coli (S6) unloaded and loaded Bacterial Isolate.

\begin{tabular}{|c|c|c|c|}
\hline Main peak $\left(\mathrm{cm}^{-1}\right)$ & $\begin{array}{l}\text { Intensity of unloaded band dead } \\
\text { bacteria }\end{array}$ & Typical band & Wave number range \\
\hline $1-3455.42$ & 50.4 & Amino acid $(\mathrm{O}-\mathrm{H})$ stretching protein $\mathrm{v}(\mathrm{N}-\mathrm{H})$ stretching & 3029-3639 \\
\hline $2-2088.62$ & 99 & Phosphate C-O Stretching band, P-H stretching & $2344-2365$ \\
\hline $3-1641.23$ & 78 & Protein amide I band mainly $(C=O)$ Stretching & $1583-1709$ \\
\hline $4-1428.99$ & 96 & $\begin{array}{l}\text { Protein }\left(\mathrm{CH}_{2}\right) \text { and }\left(\mathrm{CH}_{3}\right) \text { bending of methyl Lipid }\left(\mathrm{CH}_{2}\right) \\
\text { bending of methyl }\end{array}$ & $1425-1477$ \\
\hline $5-1109.15$ & 105 & $\begin{array}{l}\text { Carbohydrate (C-O) of polysaccharides, Nucleic acid } \\
\text { (other phosphate containing compound) }>\mathrm{P}=\mathrm{O} \\
\text { stretching of phosphodiester }\end{array}$ & $1072-1356$ \\
\hline $6-593.363$ & 92 & acid chlorides $\mathrm{C}-\mathrm{Cl}$ stretch & $730-550$ \\
\hline $7-550.577$ & 92 & acid chlorides $\mathrm{C}$-Cl stretch & $730-550$ \\
\hline
\end{tabular}

Table 7b: Data of FT-IR OF unloaded E. coli (S6) unloaded and loaded bacterial isolate.

\section{Energy dispersive X-ray (EDX)}

In our study we use Energy dispersive X-ray Figure 1 (EDX) to confirm Biosorption of $U$ by Cell-free extract loaded Ca-Alginate beads confirmed the involvement of an ion-exchange mechanism during biosorption. In order to elucidate the chemical nature of bacterial cell-bound Uranium.

(EDX) can provide information regarding the chemical and elemental characteristics of biomass. Tunali et al. analyzed both $\mathrm{Pb}^{2+}$ and $\mathrm{Cu}^{2+}$ loaded Bacillus sp. using EDX, and confirmed the involvement of an ion-exchange mechanism during biosorption [31]. In order to elucidate the chemical nature of bacterial cell-bound lanthanum. In our study we use Energy dispersive X-ray (Figure 4).

The alginate beads (Figure 3), predominantly ellipsoidal spheres, with average diameter of $3-5 \mathrm{~mm}$ were used in the packed bed to remediate $10 \mathrm{mg}^{-1} \mathrm{U}(\mathrm{VI})$ in a synthetic Uranium solution. The effectiveness of different dosages of beads was considered and the optimized ratio of 1:5 (v/v) of beads to water was used in all batch studies of isotherm kinetics. Scanning electron microscopic of these beads, Control, Waste, Figure 3 showed that these were hollow from inside (Figure 4) having smooth inner wall and a little rough outer wall (Figure 3). After interaction with the metal, the surface turned very rough (Figure 4). These calcium alginate-beads contained bacterium $E$. coli whose morphology changed from single discrete cells (Figure 5) to numerous cells forming chain-like structure when grown under metal stress (Figure 6). This established the fact that E. coli interacted with the metal present in the medium.

Kazy et al. employed X-ray diffraction (XRD) analysis and confirmed the involvement of cellular carboxyl and phosphate groups in the binding of lanthanum by Pseudomonas biomass [32]. SEM micrographs have aided researchers in analyzing cell surface morphology before and after biosorption. Tunali et al. visualized the surface of metal-loaded Bacillus sp. while in our study we employed SEM aided us in confirming $U$ biosorption study were also made to remove $U$ from $U$ wastewater using immobilized microorganisms having a high ability to adsorb $U$ [31,33-35]. Uranium refining wastewater $(100 \mathrm{~mL}, \mathrm{pH} 6.0)$ supplemented with $2.1 \mathrm{mM}$ of $U$ were adsorbed on a column (bed volume $2 \mathrm{~mL}$ ) of immobilized bacterial cells Immobilized bacterial cells isolated from $U$ mines in the Egypt can also remove $U$ from the $U$ refining wastewater with high efficiency [36-39].

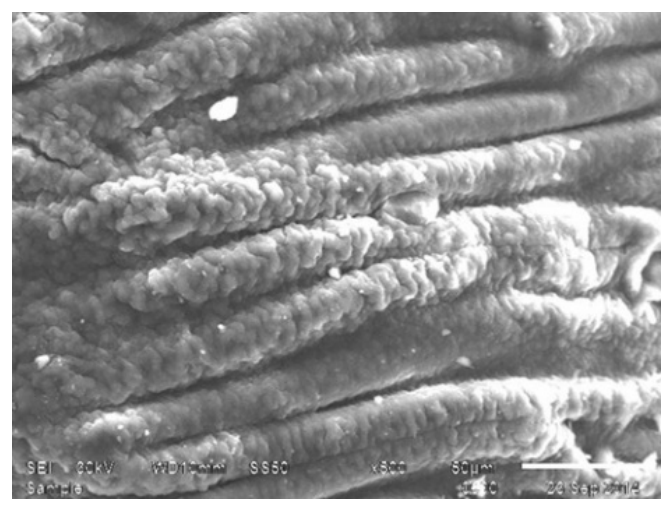

Figure 4: (EDX) to confirm Biosorption of $U$ by Cell-Free extract loaded Ca-Alginate beads. 
Citation: Fadl MG, Rezk M, Amin MM, Kamel ZM (2017) Uranium Removal from Wastewater Using Immobilized Multiple Heavy-Metal and Antibiotic Resistance E. coli Isolated from Aborshid Egypt. Adv Recycling Waste Manag 2: 145. doi:10.4172/2475-7675.1000145

Page 9 of 10

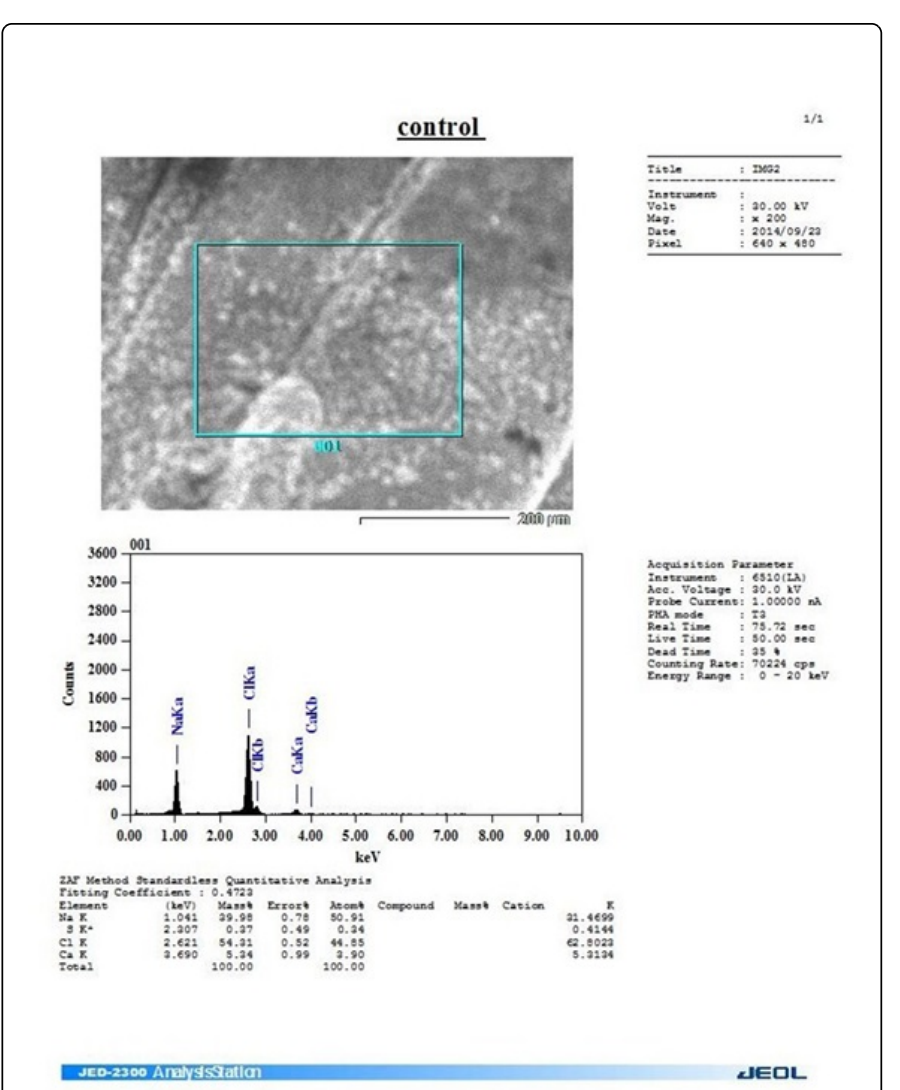

Figure 5: (EDX) by Cell-Free extract control loaded Ca-Alginate beads.
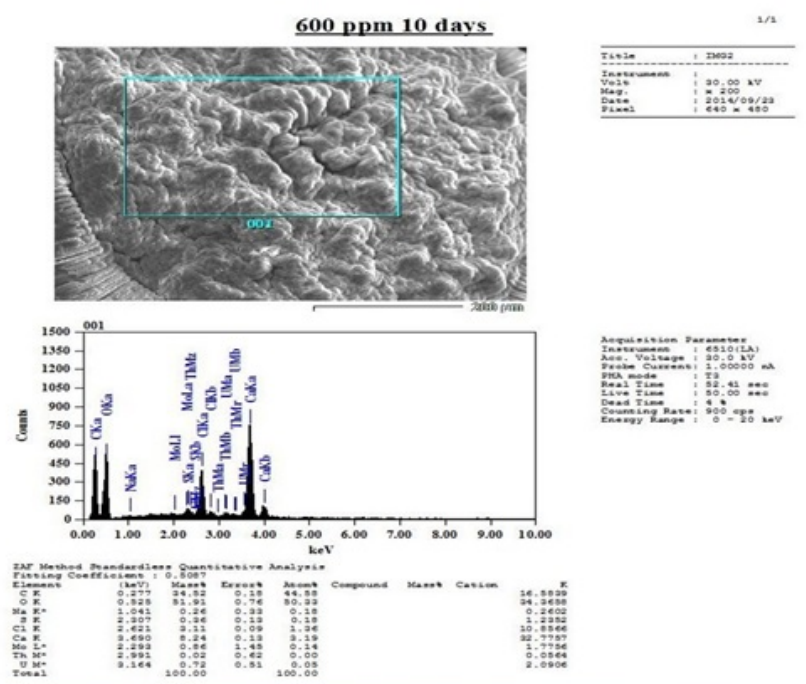

Figure 6: Bioremediation of $600 \mathrm{ppm} \mathrm{U}(\mathrm{VI})$ from synthetic solution in bottle.

\section{Conclusion}

This study confirmed that an isolated, characterized and identified novel strain of the most potent isolate was identified. The Egyptian strains belong to $E$. coli, based on $16 \mathrm{~S}$ r RNA gene sequencing the nucleotide sequences reported here were deposited to the NCBI Nucleotide Sequence Database under. could be utilized to remediate Uranium contaminated water. This report is the first of its kind where the cell-free extract of a powerful bacterium, E. coli was used as encapsulated calcium alginate beads for bioremediation through biosorption of Uranium by recycled semi-batch Burette flow process. The comparison with published literature confirmed highest remediation rate in the proposed process. The characterization experiments of the results revealed a varying response of the Ore bacteria to the tested heavy metals. All isolates showed multiple metal resistance towards Ten heavy metals, with MIC ranging from 50 to $1000 \mathrm{ppm}$, the fresh and used CFE-modified calcium alginate beads indicated that the remediation could be by biosorption of Uranium.

\section{References}

1. Jackson VA, Paulse AN, Odendaal JP, Khan S, Khan W (2012) Identification of metal-tolerant organisms isolated from the Plankenburg river, western Cape, South Africa. Water SA 38: 29-38.

2. Sharma P, Kumari P, Srivastava MM, Srivastava S (2006) Removal of cadmium from aqueous system by shelled Moringa oleifera Lam. Seed powder. Bioresour Technol 97: 299-305.

3. Park S, Lee M (2017) Removal of copper and cadmium in acid mine drainage using $\mathrm{Ca}$-alginate beads as biosorbent. J Environ Sci Health 21: 373-383.

4. An BR, Son HJ, Chung JS, Choi JW, Lee SH, et al. (2013) Calcium and hydrogen effects during sorption of copper onto an alginate-based ion exchanger: Batch and fixed-bed column studies. Chem Engineer J 232: 51-58.

5. Gourdon R, Bhende S, Rus E, Sofer SS (1990) Comparison of cadmium biosorption by Gram-positive and Gram-negative bacteria from activated sludge. Biotechnol Lett 12: 839-842.

6. Malik P, Terry TD, Bellintani F, Perham RN (1998) Factors limiting display of foreign peptides on the major coat protein of filamentous bacteriophage capsids and a potential role for leader peptidase. FEBS Lett 436: 263-266.

7. Gadd GM (1990) Heavy metal accumulation by bacteria and other microorganisms. Experientia 46: 834-839.

8. Regine HS, Vieira F, Volesky B (2000) Biosorption: A solution to pollution. Int J Microbiol 3: 17-24.

9. Ziagova M, Koukkou AI, Liakopoulou-Kyriakides M (2014) Optimization of cultural conditions of Arthrobacter sp. for growth-associated chromate(VI) reduction in free and immobilized cell systems. Chemos 95: 535-540.

10. Ahmad MF, Haydar S, Bhatti AA, Bari AJ (2014) Application of artificial neural network for the prediction of biosorption capacity of immobilized Bacillus subtilis for the removal of cadmium ions from aqueous solution. Biochem Engineer J 84: 83-90.

11. Chen BY, Chen CY, Guo WQ, Chang HW, Chen WM, et al. (2014) Fixedbed biosorption of cadmium using immobilized Scenedesmus obliquus CNW-N cells on loofa (Luffa cylindrica) sponge. Bioresour Technol 160: 175-181.

12. Panda J, Sarkar P (2012) Isolation, identification, characterization and field application of $\mathrm{Cr}(\mathrm{VI})$ resistant bacteria. J Environ Sci Health 47: 237-244.

13. Panda J, Sarkar P (2014) Biosensing and bioremediation of $\mathrm{Cr}(\mathrm{VI})$ by cell free extract of Enterobacter aerogenes T2. J Environ Sci Health 49: 600-608. 
Citation: Fadl MG, Rezk M, Amin MM, Kamel ZM (2017) Uranium Removal from Wastewater Using Immobilized Multiple Heavy-Metal and Antibiotic Resistance E. coli Isolated from Aborshid Egypt. Adv Recycling Waste Manag 2: 145. doi:10.4172/2475-7675.1000145

Page 10 of 10

14. Tomova I, Gladka G, Tashyrev O, Vasileva-Tonkova E (2014) Isolation, identification and hydrolytic enzymes production of aerobic heterotrophic bacteria from two Antarctic islands. Int J Environ Sci 4: 614-625.

15. Bauer AW, Kirby WMM, Sherris JC, Turck M (1966) Antibiotic susceptibility testing by a standardized single disc method. Am J Clin Pathol 45: 493-496.

16. Rani MJ, Hemambika B, Hemapriya J, Kannan VR (2010) Comparative assessment of heavy metal removal by immobilized and dead bacterial cells: A biosorption approach. Afr J Environ Sci Technol 4: 77-83.

17. Sabdono A, Radjasa OK, Utomo HS (2012) Screening of multimetal resistances in a bacterial population isolated from coral tissues of Central Java coastal waters. Int J Ocean Marine Ecol Syst 1: 11-23.

18. Malik A, Jaiswal R (2000) Metal resistance in Pseudomonas strains isolated from soil treated with industrial wastewater. World J Microbiol Biotechnol 16: 177-182.

19. Davies W, Gray WA (1964) Rapid and specific titrimetric method for the precise determination of uranium using iron sulphate as reductant. Tolanta 11: 1203-1211.

20. Goldstein FW (2007) Combating resistance in a challenging, changing environment. Clin Microbiol Infect 13: 2-6.

21. Kümmerer K (2009) Antibiotics in the aquatic environment-A review, Part II. Chemos 75: 435-441.

22. Séveno NA, Kallifidas D, Smalla K, van Elsas JD, Collard JM, et al. (2002) Occurrence and reservoirs of antibiotic resistance genes in the environment. Rev Med Microbiol 13: 15-27.

23. Moskot M, Kotlarska E, Jakóbkiewicz-Banecka J, GabigCiminska M, Fari $\mathrm{K}$, et al. (2012) Metal and antibiotic resistance of bacteria isolated from the Baltic Sea. Int Microbiol 15: 131-139.

24. Davison J (1999) Genetic exchange between bacteria in the environment. Plasmid 42: 73-91.

25. Herreros MA, Sandoval H, González L, Castro JM, Fresno JM, et al. (2005) Antimicrobial activity and antibiotic resistance of lactic acid bacteria isolated from Armada cheese (a Spanish goats' milk cheese). Food Microbiol 22: 455-459.

26. Zhang XX, Zhang T, Fang HHP (2009) Antibiotic resistance genes in water environment. Appl Microbiol Biotechnol 82: 397-414.

27. Miller RV, Gammon K, Day MJ (2009) Antibiotic resistance among bacteria isolated from seawater and penguin fecal samples collected near
Palmer Station, Antarctica this article is one of a selection of papers in the Special Issue on Polar and Alpine Microbiology. Can J Microbiol 55: 37-45.

28. Lo Giudice A, Casella P, Bruni V, Michaud L (2013) Response of bacterial isolates from Antarctic shallow sediments towards heavy metals, antibiotics and polychlorinated biphenyls. Ecotoxicol 22: 240-250.

29. Andrade S, Poblet A, Scagliola M, Vodopivez C, Curtosi A, et al. (2001) Distribution of heavy metals in surface sediments from an Antarctic marine ecosystem. Environ Monit Assess 66: 147-158.

30. Shevchuk IA, Klimenko NI (2009) Biological features of sorption of U (VII) and strontium ions by Bacillus polymyxa IMV 8910 cells. J Water Chem Technol 31: 324-328.

31. Kazy SK, Das SK, Sar P (2006) Lanthanum biosorption by a Pseudomonas sp. equilibrium studies and chemical characterization. J Ind Microbiol Biotech 33: 773-783.

32. Tunali S, Çabuk A, Akar T (2006) Removal of lead and copper ions from aqueous solutions by bacterial strain isolated from soil. Chem Eng J 115: 203-211.

33. Agarwal GS, Bhuptawat HK, Chaudhari S (2006) Biosorption of aqueous chromium(VI) by Tamarindus indica seeds. Bioresour Technol 97: 949-956.

34. Hassen A, Saidi N, Cherif M, Boudabous A (1998) Resistance of environmental bacteria to heavy metal. Bioresour Technol 64: 7-15.

35. Lee M, Huang DJ, Ren CC, Chang JS (2014) Fixed-bed biosorption of cadmium using immobilized Scenedesmus obliquus CNW-N cells on loofa (Luffa cylindrica) sponge. Bioresour Technol 160: 175-181.

36. Veglio F, Beolchini F (1997) Removal of metals by biosorption: A Review. Hydrometall 44: 301-316.

37. Sinha A, Pant KK, Khare SK (2012) Studies on mercury bioremediation by alginate immobilized mercury tolerant Bacillus cereus cells. Interna Biodeter Biodegrad 71: 1-8.

38. Ranquet C, Ollagnier-de-Choudens S, Loiseau L, Barras F, Fontecave M (2007) Cobalt Stress in Escherichia coli. The effect on the iron-sulfur proteins. J Biol Chem 282: 30442-30451.

39. Mishra V, Tadepalli S (2014) Biosorption of toxic heavy metals on sawdust. Clean Soil Air Wat, pp: 231-261. 